\title{
PENGARUH UKURAN PERUSAHAAN, PROFITABILITAS, SOLVABILITAS, OPINI AUDIT DAN UKURAN KANTOR AKUNTAN PUBLIK TERHADAP AUDIT DELAY PADA PERUSAHAAN MANUFAKTUR DI BURSA EFEK INDONESIA
}

\author{
Yohanes Baptista Tupen Ebang ${ }^{1}$ \\ baptista11.jb@gmail.com \\ Dr. Syaikhul Fallah, SE., M.Si ${ }^{2}$ \\ Bill J. C. Pangayow, SE., M.Si., Ak ${ }^{3}$ \\ Jurusan Akuntansi, Fakultas Ekonomi dan Bisnis Universitas Cenderawasih
}

\begin{abstract}
This study aims to analyze the effect of company size, profitability, solvency, audit opinion and the size of the public accounting firm on audit delay in manufacturing companies listed on the Indonesia Stock Exchange. The analysis was carried out using multiple linear regression analysis, where the classical assumption test was carried out first, the analysis tool using SPSS 21. The observation period in this study was 2016-2018 using a sample of 36 selected manufacturing companies based on purposive sampling with a total of 108 samples overall during 3 years of observation. The results of this study indicate that the average audit delay in manufacturing companies in 2016-2018 is 78.28 days. The results showed that the variable size of the company, profitability, solvency, audit opinion and the size of the public accounting firm did not affect audit delay. However, the independent variables simultaneously influence the dependent variable.
\end{abstract}

Keywords : :Audit Delay, Company Size, Profitability, Solvability, Audit Opinion and Size of the Public Accounting Firm.

\section{PENDAHULUAN}

Berkembangnya perusahaan go public di Indonesia menjadi signal peningkatan pada aktivitas di Bursa Efek Indonesia. Syarat utama yang dapat mendorong peningkatan harga pasar saham perusahaan - perusahaan yang telah go public adalah ketepatan waktu penyajian laporan keuangan dan (timeliness) laporan audit Togasima \& Christiawan, (2014). Perkembangan perusahaan - perusahaan yang telah go public mewajibkan perusahaan untuk menyediakan laporan keuangan yeng telah diaudit. Laporan keuangan merupakan salah komponen penting sebagai pengambilan keputusan oleh para investor. Laporan keuangan sering digunakan untuk menjadi alat ukur dan penilaian kinerja pada perusahaan. Oleh karena itu menurut Widhiasari \& Budhiarta, (2016) laporan keuangan yang baik harus memiliki beberapa karakteristik utama menurut PSAK No 1 tahun 2007 yaitu yang pertama dapat dipahami, kedua relevan, ketiga memiliki keandalan serta dapat diperbandingkan.

Kualitas informasi dari sebuah laporan keuangan perusahaan yang baik adalah kemudahannya untuk segera dapat dimengerti oleh pengguna laporan keuangan meskipun pengguna laporan keuangan tersebut kurang paham dengan ekonomi. Informasi yang tersaji dalam laporan keuangan perusahaan harus relevan. Informasi dapat dikatakan relevan jika memiliki nilai prediktif dan tepat waktu.

\footnotetext{
$\overline{{ }^{1} \text { Alumni Jurusan Akuntansi FEB Uncen }}$

${ }^{2}$ Dosen Jurusan Akuntansi FEB Uncen

3 Dosen Jurusan Akuntansi FEB Uncen
} 
Informasi dapat mempengaruhi keputusan bila informasi tersebut tersedia pada waktu yang tepat bila informasi yang disajikan sudah basi atau ketinggalan maka dapat dikatakan bahwa informasi tersebut sudah tidak dapat digunakan lagi untuk pengambilan keputusan. Salah satu masalah yang sering dihadapi untuk menghasilkan laporan keuangan yang relevan adalah ketepatan waktu. Laporan keuangan yang tertunda memiliki dampak negatif terhadap reaksi pasar. Relevansi laporan keuangan semakin diragukan bila makin lama waktu tunda pelaporan keuangan (Togasima \& Christiawan, 2014).

Laporan keuangan dapat dikatakan bermanfaat bila informasi yang terkandung di dalamnya memiliki keandalanl. Sebuah informasi dapat disebut memiliki keandalan jika dalam penyajian informasi tersebut memang benar dan tidak menyesatkan, informasi yang disampaikan juga harus bebas dari kesalahan material, dan dapat diandalkan pemakainya sebagai penyajian yang jujur dari yang seharusnya disajikan, atau yang secara wajar diharapkan dapat disajikan. Laporan keuangan harus dapat dibandingkan agar pemakai laporan keuangan dapat membandingkan laporan keuangan perusahaan antar periode untuk mengidentifikasi kecenderungan posisi keuangan.

Ketepatan waktu auditor dalam menyelesaikan auditnya mempengaruhi timeliness suatu perusahaan dalam mempublikasikan laporan keuangannya. Proses audit yang dilakukan terkadang membutuhkan waktu yang cukup lama mulai tanggal tutup buku perusahaan hingga pada saat publikasi pernyataan opini audit. Penyelengaraan mekanisme yang lemah berdampak pada lamanya proses audit yang tidak biasa dan penundaan publikasi. Menurut Wahyuni dkk, Hariza, Wahyuni, \& Maria W, (2012), hal tersebut memicu munculnya suatu selang waktu audit report lag.

Perbedaan (selisih) waktu antara tanggal laporan keuangan hingga tanggal laporan auditor ditandatangani mengindikasikan lamanya waktu penyelesaian audit oleh auditor. Perbedaan waktu tersebut yang disebut dengan audit report lag atau dapat disebut juga audit delay Prameswari \& Yustrianthe, (2015). Audit delay yang semakin lama mengindikasikan bahwa semakin lama juga auditor dalam melakukan audit. Keterlambatan penyampaian laporan keuangan akan semakin besar jika audit delay semakin lama. Audit delay sendiri dapat disebabkan oleh faktor internal maupun eksternal perusahaan.

Peraturan terkait kepatuhan ketepatan waktu dalam penyajian laporan laporan keuangan diatur oleh Badan Pengawas Pasar Modal (Bapepam) dan Lembaga Keuangan (LK) dalam peraturan No. KEP-431/BL/2012 tentang Penyampaian Laporan Tahunan Emiten atau Perusahaan Publik. Dalam peraturan tersebut dinyatakan bahwa emiten atau perusahaan publik yang pernyataan pendaftarannya telah menjadi efektif wajib menyampaikan laporan tahunan kepada Badan Pengawas Pasar Modal (Bapepam) dan Lembaga Keuangan (LK) paling lambat 4 (empat) bulan setelah tahun buku berakhir. Setelah peraturan tersebut diberlakukan diharapkan dapat mengurangi adanya keterlambatan pelaporan keuangan yang terjadi di Indonesia.

Menurut penelitian yang dilakukan oleh Zeinab Azami dan Tabandeh Salehi yang dilakukan di Teheren, India Azami \& Salehi, (2017), penundaan dalam laporan audit akan mengakibatkan keterlambatan dalam pelaporan laba akuntansi, yang mengurangi kualitas dalam pelaporan keuangan.Pada beberapa kasus di eropa audit report lag dapat memicu penurunan peluang bagi perusahaan untuk mendapatkan investasi. Sehingga pada negara - negara barat waktu keterlambatan dalam pelaporan keuangan semaksimal mungkin berusaha dikurangi.

Tujuan penelitian ini adalah untuk mengetahui pengaruh ukuran perusahaan, profitabilitas, solvabilitas, opini audit, dan ukuran kantor akuntan publik terhadap audit delay pada perusahaan manufaktur yang terdaftar di Bursa Efek Indonesia periode tahun 2016-2018. 


\section{TINJAUAN PUSTAKA}

\subsection{Teori Agensi}

Menurut Jensen \& Meckling, (1976) hubungan agensi akan terjadi pada saat terjadinya konflik kepentingan antara principal dan agent, ketika satu orang atau lebih (principal) mempekerjakan orang lain (Agent) untuk memberikan jasa, lalu memberikan wewenang untuk menjalankankan dan atau mengambil keputusan bagi perusahaan, maka pada saat itu terjadilah hubungan keagenan. Pemenenuhan tujuan utama dari manajemen keuangan adalah memaksimalkan kekayaan pemegang saham hal ini merupakan acuan dari teori agensi. Ketepatan dalam penyajian laporan keuangan audit merupakan kualitas yang berhubungan langsung dengan kualitas infoemasi yang disajikan pada saat dibutuhkan. Ketepatan pelaporan keuangan ini dapat dilihat dari seilisih waktu antara tanggal laporan keuangan dan laporan audit (audit delay).

\subsection{Stakeholder Theory}

Teori ini diperkenalkan oleh Freeman, (1984), ia menyatakan bahwa perusahaan adalah sebuah hubungan antara sebuah organisasi dengan pihak lain di luar organisasi tersebut yang memiliki kepentingan bersama. Definisi stakeholder disini termasuk pelanggan, kreditur, supplier, bahkan karyawan dan masyarakat sekitar perusahaan tersebut beroperasi Rustiarini \& Sugiarti, (2013). Oleh karena itu, berbagai pihak tersebut harus dapat menerima laporan keuangan secara tepat waktu sebagai bentuk pertanggungjawaban dari pihak manajemen perusahaan terkait pengelolaan perusahaan.

\subsection{Laporan Keuangan}

Menurut Kasmir (2012) dalam Firliana \& Sulasmiyati, (2017) "Laporan keuangan menunjukkan bagaimana keadaan keuangan perusahaan untuk saat ini maupun dalam periode tertentu". Laporan keuangan yang telah dibuat dan disajikan perusahaan merupakan sebuah alat komunikasi yang dapat digunakan untuk menunjukkan segala informasi keuangan dari perusahaan maupun kegiatan-kegiatan perusahaan kepada pihak-pihak yang berkepentingan.

\subsection{Audit Delay}

Audit delay yang semakin lama dapat berpengaruh pada informasi yang diberikan pada pihak ekstrenal perusahaan atau investor yang memerlukan laporan keuangan auditan untuk pengambilan keputusan investasi maupun untuk penilaian kinerja perusahaan layak atau tidaknya diberikan pinjaman. Semakin lamanya audit delay dapat membuat informasi yang terkandung di dalamnya bocor sehingga dapat menimbulkan efek insider trading.Menurut Prameswari \& Yustrianthe, (2015) Audit delay adalah rentang waktu penyelesaian pelaksanaan audit laporan keuangan tahunan, yang diukur berdasarkan lamanya waktu (hari) yang dibutuhkan untuk memperoleh laporan auditor independen atas laporan keuangan tahunan perusahaan, audit delay dilihat (dihitung) sejak tanggal tutup tahun buku perusahaan yaitu 31 Desember sampai tanggal yang penandatangana laporan audit yang tertera pada laporan auditor independen.

\subsection{Ukuran Perusahaan}

Pada dasarnya ukuran perusahaan dikelompokan menjadi 3 kategori utama yaitu perusahaan besar ,sedang dan kecil. Ukuran perusahaan menggambarkan besar atau kecilnya suatu perusahaan yang dapat dilihat dari total aset, kapitalisasi pasar dan total penjualan. Menurut Fadoli, (2015), perusahaan - perusahaan besar mempunyai sumber daya keuangan yang cukup kuat untuk membayar audit fee yang lebih besar guna mendapatkan pelayanan audit yang lebih cepat yang dapat mempersingkan keterlambatan pelaporan audit . Perusahaan-perusahaan besar cenderung mendapat tekanan dari pihak eksternal yang tinggi terhadap kinerja keuangan perusahaan, sehingga manajemen akan berusaha untuk mempublikasikan laporan audit dan laporan keuangan auditan lebih tepat waktu. 
Dapat kita lihat bahwa besar atau kecilnya jumlah aset yang dimiki oleh perusahaan mempengaruhi panjang atau pendeknya proses penyusunan laporan keuangan pada perusahaan tersebut.

\subsection{Profitabilitas}

Menurut beberapa penelitian profitabilitas memiliki pengaruh yang signifikan terhadap audit delay. Profitabilitas sendiri adalah merupakan kemampuan perusahaan dalam menghasilkan keuntungan melalui semua kemampuan dan sumber yang ada seperti penjualan, modal, kas, jumlah karyawan dan lain sebagainya. Beberapa penelitian mengatakan bahwa perusaahan yang mengalami keuntungan atau profit yang besar akan semakin memperkecil audit delay bila dibandingkan dengan perusahaan yang mengalami kerugian atau perusahaan yang memperoleh profit kecil, hal tersebut dikarenakan laba merupakan kabar baik yang diharapkan memilki pengaruh pada respon investor Novice \& Budi, (2010).

\subsection{Solvabilitas}

Solvabilitas merupakan kemampuan perusahaan dalam memenuhi segala kewajiban keuangannya baik kewajiban jangka panjang maupun kewajiban jangka pendek pada saat perusahaan tersebut dilikuidasi. Persentase yang tinggi dari hutang terhadap total asset akan membawa pengaruh solvabilitas yang terkait dengan masalah kelangsungan hidup sebuah perusahaan, sehingga perlu adanya kecermatan yang lebih dalam melakukan pengauditan. Akibatnya semakin tinggi prosentase dari hutang maka akan meningkatkan pula dampak dari risiko keuangannya. Rasio hutang terhadap total aset yang dinilai wajar adalah apabila aset lebih besar dari total hutang. Justira, (2017) menyatakan bahwa semakin besar rasio hutang (kewajiban) terhadap total asset maka akan berdampak pada semakin lama rentang waktu audit report lag.

\subsection{Opini Audit}

Opini audit merupakan penilaian yang diberikan oleh seorang auditor pada laporan keuangan yang telah diauditnya. Perusahaan yang diberikan qualified opinion cenderung memiliki audit delay yang lebih lama, karena secara logika dapat dikatakan bahwa auditor membutuhkan waktu dan usaha untuk mencari prosedur audit ketika mengkonfirmasi kualifikasi audit. Pendapat unqualified opinion umumnya diberikan kepada perusahaan yang terdaftar di BEI guna menunjang pelaporan hasil kinerja perusahaan Putra \& Dwiana, (2016) .

\subsection{Ukuran Kantor Akuntan Publik}

Kantor Akuntan Publik adalah lembaga keuangan yang sudah disahkan oleh pemerintah dan ditunjukan untuk para akuntan publik untuk menjalankan pekerjaanya sesuai peraturan yang berlaku. Menurut KEPMEN 423/KMK.06/2002, Kantor Akuntansi Publik (KAP) adalah badan usaha yang telah mendapatkan izin dari menteri sebagai wadah dari akuntan publik dalam memberikan jasanya. Ukuran kantor akuntan publik dikategorikan dalam KAP Big Four dan KAP Non Big Four. Di Indonesia sendiri telah terdapat beberapa kantor akuntan publik yang besar dan memiliki reputasi bagus dan termasuk KAP Big Four sebagai berikut Kantor Akuntan Publik (KAP) Tanudiredja, Wibisana \& Rekan yang merupakan afiliasi dari KAP PWC, KAP Osman Bing Satrio berafiliasi dengan Deloitte Tauche Thomatshu, KAP Purwantono, Suherman, \& Surja berafiliasi dengan Ernst \& Young dan KAP Sidharta dan Widjaja berafiliasi dengan KPMG (Klynfeld Peat Marwick Goedelar).

\subsection{Penelitian Terdahulu dan Pengembangan Hiptesis}

\subsubsection{Pengaruh Ukuran Perusahaan Terhadap Audit Delay}

Penelitian yang dilakukan oleh Christian Noverta Togasima dan Yulius Jogi Christiawan (2014) membuktikan bahwa ukuran perusahaan berpengaruh terhadap audit delay hasil yang sama juga ditemui oleh Justira, (2017), Zakaria, Anggraini, \& Mutiara, (2018) dan Cahyanti, Sudjana, \& Azizah, (2016) yang membuktikan bahwa ukuran perusahaan berpengaruh terhadap audit delay namun hasil yang berbeda ditemui oleh Lianto \& Kusuma, (2010), Saemargani \& Rr. Indah Mustikawati, M.si., 
(2015), Fadoli, (2015), Prameswari \& Yustrianthe, (2015) dan Widhiasari \& Budhiarta, (2016) yang membuktikan bahwa ukuran perusahaan tidak berpengaruh terhadap audit delay .

H1 : Ukuran Perusahaan berpengaruh terhadap audit delay.

\subsubsection{Pengaruh Profitabilitas Terhadap Audit Delay}

Penelitian yang dilakukan oleh Okalesa, (2018) menguji pengaruh profitabilitas terhadap audit delay memperoleh hasil hasil bahwa profitabilitas berpengaruh terhadap audit delay hasil tersebut konsisten dengan hasil yang ditemui oleh Lianto \& Kusuma, (2010), Nisak, (2015), Justira, (2017) dan Isti, (2017), sedangkan hasil berbeda ditemui oleh Togasima \& Christiawan, (2014) dan Fadoli, (2015) yang menemukan bahwa audit delay tidak dipengaruhi oleh profitabilitas.

H2 : Profitabilitas berpengaruh terhadap audit delay.

\subsubsection{Pengaruh Solvabilitas Terhadap Audit Delay}

Solvabilitas adalah kemampuan perusahaan untuk memenuhi kewajibannya.Penelitian yang dilakukan oleh Candraningtiyas, Sulindawati, \& Wahyuni, (2017) menguji pengaruh solvabilitas pada audit memperoleh hasil solvabilitas berpengaruh terhadap audit delay dimana hasil tersebut sejalan dengan hasil yang ditemui oleh Lianto \& Kusuma, (2010), Nisak, (2015) dan Okalesa, (2018), namun hasil sebaliknya ditemukan oleh Togasima \& Christiawan, (2014), Prameswari \& Yustrianthe, (2015) dan Liwe, Manossoh, \& Mawikere, (2018) yang menemukan bahwa solvabilitas tidak berpengaruh terhadap audit delay.

H3 : Solvabilitas berpengaruh terhadap audit delay.

\subsubsection{Pengaruh Opini Audit Terhadap Audit Delay}

Penelitian yang dilakukan oleh Togasima \& Christiawan, (2014) terkait faktor - faktor yang berpengaruh terhadap audit delay menguji pengaruh opini audit terhadap audit delay hasilnya menunjukan bahwa opini audit berpengaruh terhadap audit delay hasil penelitian sejalan dengan penelitian yang dilakukan oleh Hariza et al., (2012), Putra \& Dwiana, (2016), Kusumawardani, (2013) dan Sumartini (2014) yang membuktikan bahwa opini audit beperngaruh terhadap audit delay, namun hasil penelitian lain yang dilakukan oleh Saemargani \& Rr. Indah Mustikawati, M.si., (2015), Fadoli, (2015) dan Prameswari \& Yustrianthe, (2015) memperoleh hasil penelitian sebaliknya dimana opini audit tidak berpengaruh terhadap audit delay.

H4 : Opini Audit berpengaruh terhadap audit delay.

\subsubsection{Pengaruh Ukuran Kantor Akuntan Publik Terhadap Audit Delay}

Penelitian yang dilakukan oleh Kusumawardani, (2013) menguji pengaruh ukuran kantor akuntan publik pada audit delay yang membuktikan bahwa ukuran kantor akuntan publik berpengaruh terhadap audit delay, hasil penelitian tersebut sejalan dengan penelitian yang dilakukan oleh, Ketut \& Made, (2014) namun hasil sebaliknya ditemukan oleh Sumartini \& Widhiyani, (2014), Togasima \& Christiawan, (2014) dan Saemargani \& Rr. Indah Mustikawati, M.si., (2015) yang menemukan hasil bahwa ukuran kantor akuntan publik tidak berpengaruh terhadap audit delay.

H5 : Ukuran Kantor Akuntan Publik tidak berpengaruh terhadap audit delay. 


\subsection{Model Penelitian}

Model penelitian dapat dilihat seperti gambar dibawah ini :

Gambar 1

Model Penelitian

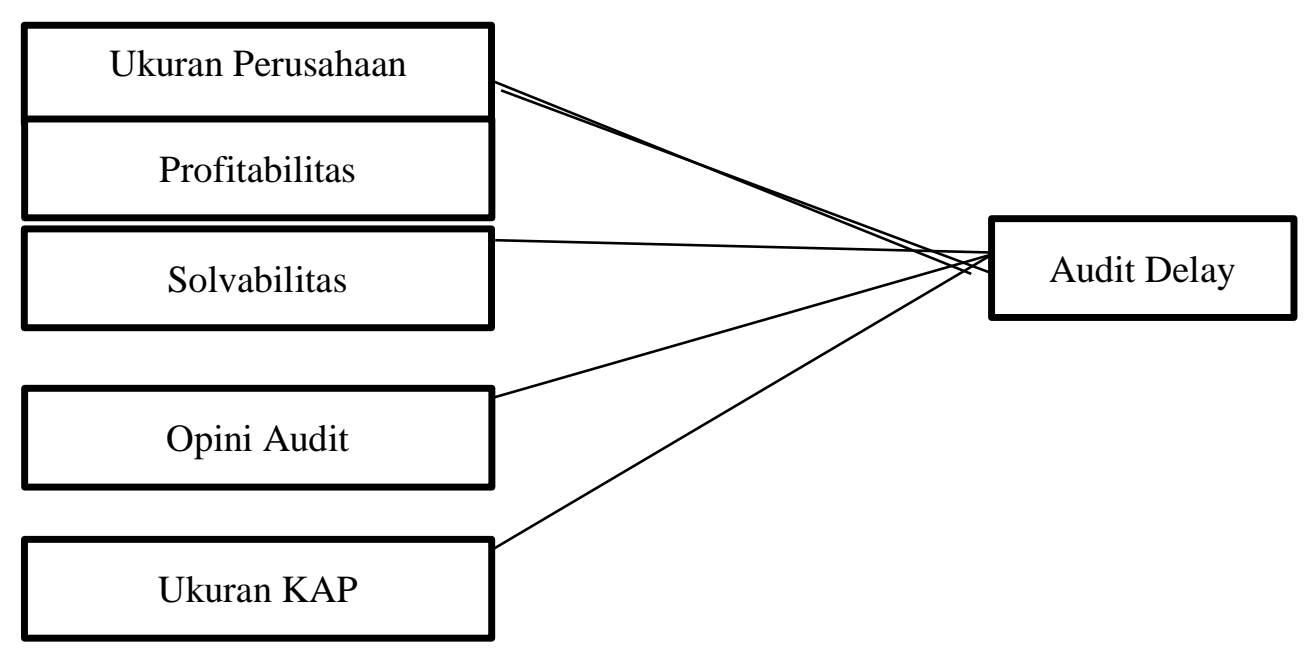

Sumber: Penulis 2019

\section{MODEL PENELITIAN}

\subsection{Jenis dan Sumber Data}

Penelitian ini menggunakan data sekunder berupa laporan keuangan tahunan perusahaan yang telah di audit. Data diperoleh dari Bursa Efek Indonesia sesuai dengan tahun penelitian yaitu tahun 2016, tahun 2017 dan tahun 2018.

\subsection{Pemilihan Sampel dan Pengumpulan Data}

Penelitian ini menggunakan sampel yang ditentukan melalui teknik pengambilan sampel bertujuan atau biasa dikenal dengan teknik purposive sampling yaitu teknik pengambilan sampel dari populasi dengan berdasar pada kriteria tertentu.Berdasarkan pada penjelasan tersebut maka peneliti menetukan beberapa kriteria untuk pengambilan sampel guna memperoleh sampel yang sesuai dengan penelitian yang akan dilakukan, kriteria tersebut sebagai berikut :

1. Perusahaan manufaktur yang terdaftar di Bursa Efek Indonesia pada tahun 2016-2018.

2. Menerbitkan laporan keuangan di Bursa Efek Indonesia dalam mata uang rupiah periode tahun 2016-2018.

3. Perusahaan tersebut tidak melakukan akuisisi atau merger pada tahun 2016-2018.

4. Perusahaan tidak mengalami kerugian selama periode pengamatan yaitu tahun 2016-2018.

5. Perusahaan memiliki data yang lengkap dan sesuai dengan variabel yang akan diteliti.

\subsection{Definisi Operasional Dan Pengukuran Variabel Variabel Dependen}

Dalam penelitian ini variebel dependen yang digunakan adalah audit delay. Audit delay merupakan selisih waktu (hari) yang dilihat melalui tanggal penutupan tahun buku hingga tanggal penandatanganan laporan audit. Semakin lama rentang waktu pelaporan audit dari tanggal penutupan buku maka dapat dikatakan semakin lama audit delay suatu perusahaan.

Audit Delay $=$ Tanggal Tutup Tahun Buku - Tanggal Laporan Keuangan 


\section{Variabel Independen}

\section{a. Ukuran Perusahaan}

Mengacu pada penelitian yang dilakukan oleh Fadoli, (2015) Ukuran perusahaan diukur dengan melihat jumlah total aktiva(log) yang dimiliki oleh perusahaan.

Ukuran Perusahaan $=$ Ln Total Assets

\section{b. Profitabilitas}

Variabel Profitabilitas adalah kemampuan perusahaan untuk mendapatkan keuntungan dalam hubungannya dengan total aktiva maupun modal sendiri serta penjualan dan kemampuan lainnya. Pada penelitian ini penulis mengukur profitabilitas dengan menggunakan rasio return on asset (ROA) dengan menggunakan rumus laba bersih setelah pajak dibagi dengan total aktiva yang mengacu pada penelitian yang dilakukan oleh Hariza et al., (2012).

Return On Asset $=\frac{\text { Laba Bersih Setelah Pajak }}{\text { Total Aktiva }}$

\section{c. Solvabilitas}

Solvabilitas merupakan kemampuan perusahaan untuk memenuhi kewajiban keuangannya baik kewajiban jangka panjang maupun jangka pendek. Variabel solvabilitas diproksikan dengan menggunakan debt to assets ratio yang diukur dari total kewajiban dibagi dengan total aktiva.

Debt To Assets $=\frac{\text { Total Hutang }}{\text { Total Aktiva }}$

\section{d. Opini Audit}

Opini audit merupakan pendapat atau opini yang diberikan oleh auditor atas kewajaran laporan keuangan suatu perusahaan berdasar pada bukti - bukti audit yang dimiliki atau ditemukan. Penelitian ini menggunakan dua klasifikasi pendapat auditor, yaitu wajar tanpa pengecualian (nilai dummy 1) dan selain wajar tanpa pengecualian (nilai dummy 0 ).

\section{e. Ukuran Kantor Akuntan Publik}

Ukuran kantor akuntan publik pada penelitian ini dipisahkan menjadi KAP Big Four (1) dan KAP Non Big Four (0) yang dilihat menggunakan variabel dummy.

\subsection{Teknis Analisa Data Statistik Deskriptif}

Statistik deskriptif berfungsi sebagai penganalisis data dengan menggambarkan sampel data yang telah dikumpulkan tanpa penggeneralisasian. Penelitian ini menjabarkan jumlah data, rata-rata, nilai minimum dan maksimum, dan standar deviasi.

\section{Uji Asumsi Klasik}

Untuk memperoleh model regresi yang memberikan hasil Best Linear Unbiased Estimator (BLUE), model tersebut perlu diuji asumsi klasik dengan metode Ordinary Least Square (OLS) atau pangkat kuadrat terkecil biasa. Model regresi dikatakan BLUE apabila tidak terdapat Autokorelasi, Multikolinearitas, Heteroskedastisitas, dan Normalitas.

\section{Uji Linear Berganda}

Untuk melakukan pengujian atas hipotesis yang diajukan pada penelitian ini peneliti menggunakan metode analisis regresi linier berganda. Analisis regresi linier berganda digunakan untuk menguji pengaruh antara audit delay dengan variabel bebas (independen).

Model regresi linier berganda yang digunakan adalah dengan menggunakan rumus Justira, (2017) : 
$\mathrm{Y}=\mathrm{a}+\beta 1 \mathrm{X} 1+\beta 2 \mathrm{X} 2+\beta 3 \mathrm{X} 3+\beta 4 \mathrm{X} 4+\beta 5 \mathrm{X} 5+\mathrm{e}$

Keterangan:

$\mathrm{Y}=$ Audit Delay

$a=$ Konstanta $\beta 1-\beta 5=$ Koefisien regresi dari X1, X2, X3, X4, X5

$\mathrm{X} 1=$ Ukuran Perusahaan

$\mathrm{X} 2=$ Profitabilitas

$\mathrm{X} 3$ = Solvabilitas

X4 = Opini Audit

X5 = Ukuran Kantor Akuntan Publik

$\mathrm{e}=$ Error

\section{HASIL DAN PEMBAHASAN}

\subsection{Deskripsi Objek Penelitian}

Penelitian yang dilakukan bertujuan untuk menguji apakakah variabel audit delay dipengaruhi oleh variabel ukuran perusahaan, profitabilitas, solvabilitas, opini audit dan ukuran kantor akuntan publik. Penelitian ini menggunakan perusahaan - perusahaan manufaktur yang terdaftar di Bursa Efek Indonesia pada tahun 2016-2018 sebagai objek penelitian. Populasi awal yang akan diteliti yaitu sebanyak 141 perusahaan terdaftar. Dari hasil pengumpulan data yang telah dilakukan penulis, maka diperoleh sampel sebanyak 36 perusahaan manufaktur. Distribusi pengambilan sampel penelitian yakni sebagai berikut :

Tabel 1

\begin{tabular}{|c|l|c|}
\hline Langkah & \multicolumn{1}{|c|}{ Keterangan } & $\begin{array}{c}\text { Jumlah } \\
\text { Perusahaan }\end{array}$ \\
\hline 1 & $\begin{array}{l}\text { Perusahaan manufaktur yang terdaftar di Bursa } \\
\text { Efek Indonesia pada tahun 2016-2018. }\end{array}$ & 141 \\
\hline 2 & $\begin{array}{l}\text { Menerbitkan laporan keuangan di Bursa Efek } \\
\text { Indonesia dalam mata uang rupiah periode } \\
\text { tahun 2016-2018. }\end{array}$ & $(67)$ \\
\hline 3 & $\begin{array}{l}\text { Perusahaan tersebut tidak melakukan akuisisi } \\
\text { atau merger pada tahun 2016-2018. }\end{array}$ & $(4)$ \\
\hline 4 & $\begin{array}{l}\text { Perusahaan tidak mengalami kerugian selama } \\
\text { periode pengamatan yaitu tahun 2016-2018. }\end{array}$ & $(27)$ \\
\hline 5 & Outlayer Data & 36 \\
\hline Jumlah Sampel & \multicolumn{1}{|c|}{ (7) } \\
\hline \multicolumn{2}{|l|}{ Total sampel yang diteliti pada tahun 2016-2018 adalah 36 x $3=108$} \\
\hline
\end{tabular}

\subsection{Statistik Deskriptif}

Statistik deskriptif berfungsi sebagai penganalisis data dengan menggambarkan sampel data yang telah dikumpulkan tanpa penggeneralisasian. Penelitian ini menjabarkan jumlah data,nilai ratarata, nilai minimum dan maksimum, range, sum dan standar deviasi. Statistik deskriptif penelitian dapat dilihat pada tabel berikut : 
Descriptive Statistics

\begin{tabular}{|l|l|l|l|l|l|}
\hline & $\mathrm{N}$ & Minimum & Maximum & Mean & $\begin{array}{l}\text { Std. } \\
\text { Deviation }\end{array}$ \\
\hline Audit Delay & 108 & 57,0000 & 89,0000 & 78,287037 & 8,6985345 \\
\hline $\begin{array}{l}\text { Ukuran } \\
\text { Perusahaan }\end{array}$ & 108 & 21,6849 & 33,4737 & 28,470691 & 2,0482066 \\
\hline Profitabilitas & 108 &, 0003 &, 7816 &, 070337 &, 0864243 \\
\hline $\begin{array}{l}\text { Solvabilitas } \\
\text { Valid N }\end{array}$ & 108 &, 0985 & 1,6595 &, 399298 &, 2187729 \\
\hline \begin{tabular}{l} 
(listwise) \\
\hline
\end{tabular} & 108 & & & & \\
\hline
\end{tabular}

Sumber : Data Olahan SPSS

Berdasarkan pada tabel statistik deskriptif di atas maka dapat dilihat bahwa audit delay paling cepat adalah 57 hari dan audit delay terlama adalah 89 hari dengan rata-rata sebesar 78,28 hari. Dapat dilihat bahwa audit delay yang terjadi masih dalam rentang lama waktu pelaporan audit yang ditetapkan oleh BAPEPAM, sehingga perusahaan manufaktur dalam sampel dan periode pengamatan tidak dikenakan sanksi.

Ukuran perusahaan dilihat menggunakan Ln Total aset, dapat dilihat pada tabel diatas bahwa nilai ukuran perusahaan terendah adalah 21, 6849 dan nilai tertinggi 33,4737.

Profitabilitas dilihat berdasarkan Laba Setelah Pajak dibagi dengan Total Aset. Pada tabel diatas dapat dilihat bahwa nilai profitabilitas terendah adalah 0,0003 dan nilai tertinggi 0,7816 dengan ratarata 070337. Dapat dilihat bahwa terdapat perbedaan yang cukup signifikan antara perolehan laba setiap perusahaan manufaktur di BEI.

Solvabilitas merupakan kemampuan perusahaan dalam melunasi kewajibannya bila terjadi likuidasi dihitung berdasarkan perbandingan antara total kewajiban dengan totas aset. Pada tabel di atas dapat dilihat bahwa nilai solvabilitas terendah adalah 0,0985 dan nilai solvabilitas terbesar adalah 1,6595 dengan rata-rata sebesar 0,399298.

\subsection{Hasil Uji Asumsi Klasik}

\section{a. Uji Normalitas}

Hasil uji normalitas dapat dilihat sebagai berikut :

One-Sample Kolmogorov-Smirnov Test

\begin{tabular}{|ll|l|}
\hline & & Unstandardized Residual \\
\hline $\mathrm{N}$ & Mean & 108 \\
Normal Parameters & a, &, 0000000 \\
& Std. Deviation & 8,37791924 \\
Most Extreme Differences & Absolute &, 112 \\
& Positive &, 094 \\
& Negative &,- 112 \\
Kolmogorov-Smirnov Z & 1,163 \\
Asymp. Sig. (2-tailed) &, 134 \\
\hline a. Test distribution is Normal. & \\
b. Calculated from data. & \\
Sumber: Data Olahan SPSS &
\end{tabular}


Pada tabel diatas dapat dilihat bahwa nilai probabilitas sebesar 0,134 atau lebih besar dari 0,05 maka dapat dikatakan bahwa data diatas telah memnuhi asumsi normalitas atau data terdistribusi secara normal.

\section{b. Uji Heterokedastisitas}

Berikut ini uji heteroskeditas pada penelitian ini :

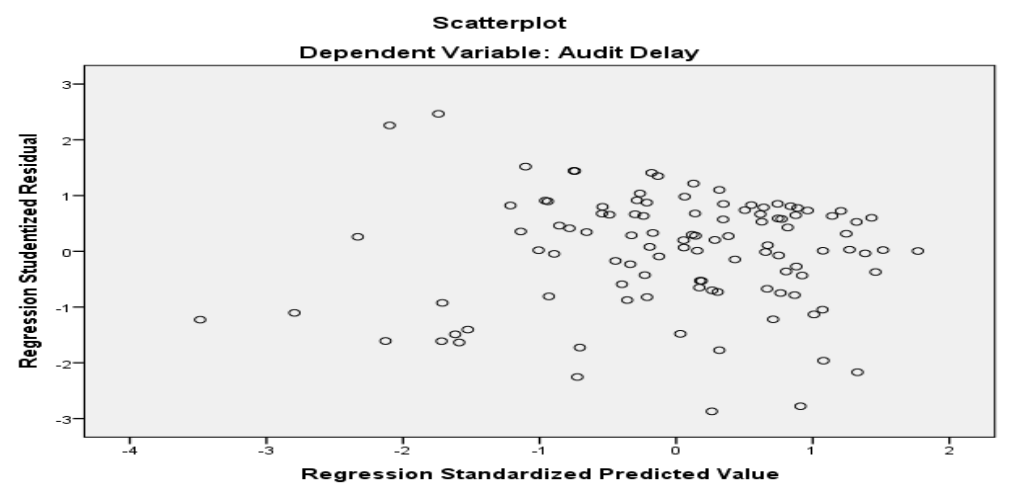

Sumber: Hasil olahan SPSS

Pada gambar diatas dapat dilihat bahwa tidak terbentuk pola tertentu dan tersebar secara acak dengan demikian dapat disimpulkan bahwa data yang digunakan dalam penelitian ini tidak mengandung heteroskeditas.

\section{c. Uji Autokorelasi}

Autokorelasi muncul karena pengamatan yang berurutan sepanjang waktu berkaitan satu sama lain. Berikut ini dapat dilihat tabel uji autokorelasi :

\begin{tabular}{|c|c|c|c|}
\hline $\mathrm{dU}$ & $4-\mathrm{dU}$ & $\mathrm{DW}$ & Interpretasi \\
\hline 1,7832 & 2,2168 & 2,077 & $\begin{array}{l}\text { Tidak Terjadi } \\
\text { AutoKorelasi }\end{array}$ \\
\hline
\end{tabular}

Sumber: Data diolah penulis

Berdasarkan pada nilai DW di atas maka dapat disimpulkan bahwa tidak terjadi autokorelasi dimana nilai DW berada dintara dU dan 4-dU .

\subsection{Pengujian Hipotesis}

\section{a. Ketepatan Perkiraan Model}

Berdasarkan pada tabel di atas dapat dilihat bahwa nilai R2 sebesar 0,204 atau 20\%. Dapat disimpulkan bahwa pengaruh variabel ukuran perusahaan, profitabilitas, solvabilitas, opini audit dan ukuran kantor akuntan publik terhadap variabel dependen audit delay sebesar $20 \%$ sedangkan $80 \%$ dipengaruhi oleh variabel lain diluar penelitian ini.

\section{b. Uji T}

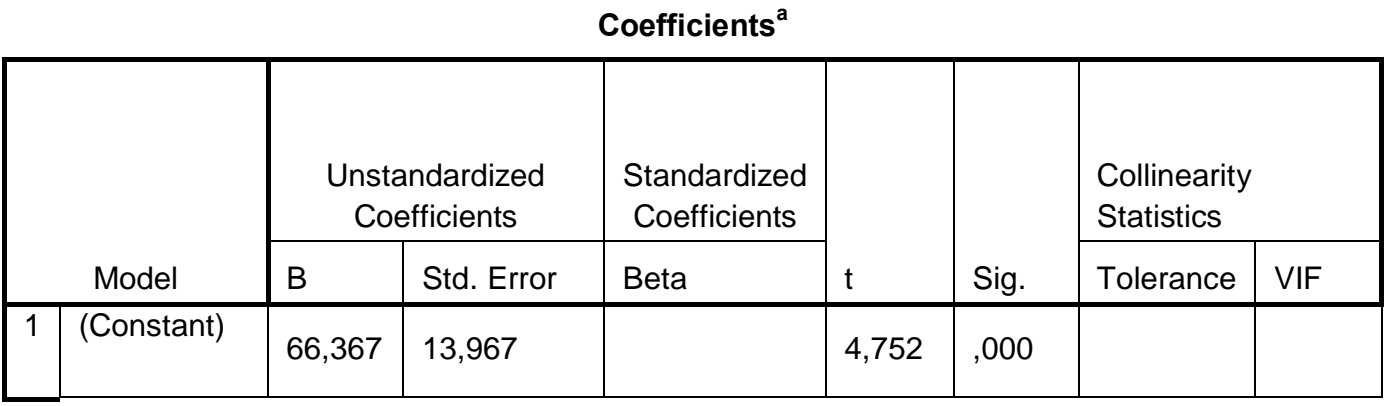




\begin{tabular}{|l|l|l|l|l|l|l|l|}
\hline $\begin{array}{l}\text { Ukuran } \\
\text { Perusahaan }\end{array}$ &,- 695 &, 421 &,- 164 & $-1,649$ &, 102 &, 763 & 1,311 \\
\hline Profitabilitas & $-6,750$ & 9,733 &,- 067 &,- 694 &, 490 &, 800 & 1,249 \\
\hline Solvabilitas & $-1,106$ & 3,535 &,- 028 &,- 313 &, 755 &, 949 & 1,054 \\
\hline Opini Audit & $-2,598$ & 1,978 &,- 117 & $-1,314$ &, 192 &, 953 & 1,050 \\
\hline $\begin{array}{l}\text { Ukuran } \\
\text { KAP }\end{array}$ & 1,419 & 1,739 &, 082 &, 816 &, 416 &, 750 & 1,333 \\
\hline lag_y &, 435 &, 090 &, 434 & 4,855 &, 000 &, 938 & 1,066 \\
\hline
\end{tabular}

a. Dependent Variable: Audit Delay Sumber: Hasil Olah SPSS

\begin{tabular}{|c|c|c|c|c|c|}
\hline \multicolumn{6}{|c|}{ Model Summary ${ }^{\circ}$} \\
\hline Model & $\mathrm{R}$ & $\begin{array}{l}\mathrm{R} \\
\text { Square }\end{array}$ & $\begin{array}{l}\text { Adjusted } \mathrm{R} \\
\text { Square }\end{array}$ & $\begin{array}{l}\text { Std. Error } \\
\text { of the } \\
\text { Estimate }\end{array}$ & $\begin{array}{l}\text { Durbin- } \\
\text { Watson }\end{array}$ \\
\hline 1 & $499^{2}$ & 249 & 204 & 7,7842220 & 2,077 \\
\hline
\end{tabular}

a. Predictors: (Constant), lag_y, Opini Audit, Solvabilitas, Ukuran Perusahaan, Profitabilitas, Ukuran KAP

b. Dependent Variable: Audit Delay Data olahan SPSS

\begin{tabular}{|l|l|l|l|l|l|l|l|}
\hline $\begin{array}{l}\text { Ukuran } \\
\text { KAP }\end{array}$ & 1,419 & 1,739 &, 082 &, 816 &, 416 &, 750 & 1,333 \\
\hline lag_y &, 435 &, 090 &, 434 & 4,855 &, 000 &, 938 & 1,066 \\
\hline
\end{tabular}

a. Dependent Variable: Audit Delay Hasil Olah SPSS

Dari tabel di atas maka dibuat persamaan regresi sebagai berikut :

$$
\mathrm{Y}=66,367-0,695 X_{1}-6,750 X_{2}-1,106 X_{3}-2,598 X_{4}+1,419 X_{5}+\mathrm{e}
$$

Nilai konstanta sebesar 66,367. Ini menunjukan bahwa jika variabel independen bernilai nol, maka tingkat audit delay sebesar 66,37 hari.

Dari tabel di atas dapat dilihat bahwa variabel ukuran perusahaan, profitabilitas, solvabilitas, opini audit dan ukuran kantor akuntan publik secara parsial tidak berpengaruh terhadap variabel dependen audit delay.

\subsection{Pembahasan Hipotesis}

Pengaruh Ukuran Perusahaan Terhadap Audit Delay

H1 : Ukuran Perusahaan berpengaruh terhadap audit delay.

Pada tabel di atas dapat dilihat bahwa hasil koefisien regresi untuk variabel ukuran perusahaan dengan nilai signifikansi sebesar 0,102 lebih besar dari 0,05 dengan kata lain bahwa variabel ukuran perusahaan tidak berpengaruh terhadap audit delay, maka hipotesis 
pada penelitian ini ditolak. Nilai koefisien regresi $X_{1}$ sebesar -0,695 menunjukan bahwa jika variabel independen lain konstan, maka kenaikan ukuran perusahaan senilai Rp 1 akan mengakibatkan penurunan audit delay sebesar Rp. 0,695.

Hasil penelitian ini sejalan dengan penelitian yang dilakukan oleh Novice \& Budi, (2010), Saemargani \& Rr. Indah Mustikawati, M.si., (2015), Fadoli, (2015), Prameswari \& Yustrianthe, (2015), dan Widhiasari \& Budhiarta, (2016), yang menemukan hasil bahwa ukuran perusahaan tidak berpengaruh terhadap audit delay. Ukuran perusahaan yang kecil atau besar ternyata tidak memberi pengaruh dalam proses audit karena semua prosedur pelaksanaan audit akan tetap sama baik pada perusahaan besar maupun kecil.

\section{Pengaruh Profitabilitas Terhadap Audit Delay}

\section{H2 : Profitabilitas berpengaruh terhadap audit delay.}

Pada tabel di atas dapat dilihat bahwa hasil koefisien regresi untuk variabel profitabilitas dengan nilai signifikansi sebesar 0,490 lebih besar dari 0,05 dengan kata lain bahwa variabel profitabilitas tidak berpengaruh terhadap audit delay, maka hipotesis pada penelitian ini ditolak. Nilai koefisien regresi $X_{2}$ sebesar -6,750 menunjukan bahwa jika variabel independen lain konstan, maka kenaikan $1 \%$ profitabilitas akan mengakibatkan penurunan audit delay sebesar $0,695 \%$.

Hasil penelitian ini sejalan dengan penelitian yang dilakukan oleh Togasima \& Christiawan, (2014) dan Fadoli, (2015), yang menemukan hasil bahwa profitabilitas tidak berpengaruh terhadap audit delay.

\section{Pengaruh Solvabilitas Terhadap Audit Delay}

\section{H3 : Solvabilitas berpengaruh terhadap audit delay.}

Pada tabel di atas dapat dilihat bahwa hasil koefisien regresi untuk variabel solvabilitas dengan nilai signifikansi sebesar 0,755 lebih besar dari 0,05 dengan kata lain bahwa variabel solvabilitas tidak berpengaruh terhadap audit delay, maka hipotesis pada penelitian ini ditolak. Nilai koefisien regresi $X_{3}$ sebesar -1,106 menunjukan bahwa jika variabel independen lain konstan, maka kenaikan $1 \%$ solvabilitas akan mengakibatkan kenaikan audit delay sebesar $1,106 \%$.

Hasil serupa ditemui oleh Togasima \& Christiawan, (2014), Prameswari \& Yustrianthe, (2015) dan Liwe, Manossoh, \& Mawikere, (2018) yang menemukan hasil bahwa solvabilitas tidak berpengaruh terhadap audit delay. Perusahaan dengan tingkat kewajiban yang tinggi maupun rendah ternyata tidak berdampak pada audit delay karena poroses audit yang dilakukan auditor sesuai prosedur dan memajemen waktu dengan baik pada saat proses audit hutang.

\section{Pengaruh Opini Audit Terhadap Audit Delay}

\section{H4 : Opini Audit berpengaruh terhadap audit delay.}

Pada tabel 4.9 di atas dapat dilihat bahwa hasil koefisien regresi untuk variabel opini audit dengan nilai signifikansi sebesar 0,192 lebih besar dari 0,05 dengan kata lain bahwa variabel opini audit tidak berpengaruh terhadap audit delay, maka hipotesis pada penelitian ini ditolak.

Hasil penelitian ini sejalan dengan penelitian yang dilakukan oleh Saemargani \& Rr. Indah Mustikawati, M.si., (2015), Prameswari \& Yustrianthe, (2015) dan Fadoli, (2015) yang menemukan hasil bahwa opini audit tidak berpengaruh terhadap audit delay. 


\section{Pengaruh Ukuran Kantor Akuntan Publik Terhadap Audit Delay}

H5 : Ukuran Kantor Akuntan Publik tidak berpengaruh terhadap audit delay.

Pada tabel 4.9 di atas dapat dilihat bahwa hasil koefisien regresi untuk variabel ukuran kantor akuntan publik dengan nilai signifikansi sebesar 0,416 lebih besar dari 0,05 dengan kata lain bahwa variabel ukuran kantor akuntan publik tidak berpengaruh terhadap audit delay, maka hipotesis pada penelitian ini diterima.

Hasil penelitian ini sejalan dengan penelitian yang dilakukan oleh Sumartini \& Widhiyani, (2014), Togasima \& Christiawan, (2014) dan Saemargani \& Rr. Indah Mustikawati, M.si., (2015), yang menemukan hasil bahwa ukuran kantor akuntan publik tidak berpengaruh terhadap audit delay.

\section{PENUTUP}

\subsection{Kesimpulan}

Analisis dilakukan dengan menggunakan analisis regresi linear berganda, dimana uji asumsi klasik dilakukan terlebih dahulu, alat analisis menggunakan SPSS 21. Periode pengamatan dalam penelitian ini adalah tahun 2016-2018 dengan menggunakan sampel 36 perusahaan manufaktur terpilih berdasarkan purposive sampling dengan total 108 sampel secara keseluruhan selama 3 tahun pengamatan. Diperoleh beberapa kesimpulan sebagai berikut :

1. Model penelitian dinyatakan lolos uji asumsi klasik, yakni memenuhi asumsi normalitas, tidak terdapat gejala heteroskeditas, multikolinearitas, dan autokorelasi. Nilai R2 sebesar 0,204 atau $20 \%$ dapat disimpulkan bahwa variabel independen hanya mempengaruhi variabel sebesar $20 \%$ sedangkan $80 \%$ dipengaruhi oleh variabel lain diluar penelitian.

2. Rata-rata audit delay pada perusahaan manufaktur pada tahun 2016-2018 adalah 78,28 hari. Hasil penelitian menunjukan bahwa variabel ukuran perusahaan, profitabilitas, solvabilitas, opini audit dan ukuran kantor akuntan publik tidak berpengaruh terhadap audit delay.

\subsection{Keterbatasan}

Penulis menyadari bahwa penelitian ini masih memiliki banyak keterbatasan, antara lain : Sampel yang terbatas sehingga kurang menjelaskan keadaan pada perusahaan - perusahaan yang terdaftar di Bursa Efek Indonesia.Periode Pengamatan yang singkat.Variabel yang kurang menjelaskan fenomena audit delay yang terjadi, dimana pada penelitian ini hanya mampu menjelaskan $20 \%$ pengaruh.

\subsection{Saran}

Penelitian selanjutnya sebaiknya memperluas sampel pengamatan dan menambah variabel independen lain selain variabel yang digunakan dalam penelitian.Memperpanjang periode pengamatan guna memperoleh hasil yang berbeda. Penambahan variabel lain selain variabel yang telah diteliti pada penelitian ini contohnya jenis industri, umur perusahaan, dan likuiditas. 


\section{DAFTAR PUSTAKA}

Cahyanti, D. N., Sudjana, N., \& Azizah, D. F. (2016). Pengaruh Ukuran Perusahaan, Profitabilitas, dan Solvabilitas Terhadap Audit Delay (Studi Pada Perusahaan LQ 45 Sub-Sektor Bank serta Property dan Real Estate yang Terdaftar di Bursa Efek Indonesia (BEI) Tahun 2010 - 2014). Administrasi Dan Bisnis, vol 38 No, 68-73.

Candraningtiyas, E. G., Sulindawati, N. L. G. E., \& Wahyuni, M. A. (2017). Pengaruh Ukuran Perusahaan, Profitabilitas, Solvabilitas, dan Ukuran Kantor Akuntan Publik Terhadap Audit Delay Pada Perusahaan Perbankan Yang Terdaftar di BEI 2012-2015. E-Journal S1 Ak Universitas Pendidikan Ganesha, Vol 8 No 2.

Fadoli, I. (2015). Pengaruh Faktor Internal dan Eksternal Terhadap Audit Report Lag (Studi Empiris Pada Perusahaan Manufaktur dan Perbankan yang Terdaftar di BEI Tahun 2008-2013).

Firliana, I., \& Sulasmiyati, S. (2017). Pengaruh Ukuran Perusahaan, Profitabilitas, dan Solvabilitas Terhadap Audit Delay (Studi Pada Perusahaan LQ 45 Sub-Sektor Bank serta Manufaktur yang Terdaftar di Bursa Efek Indonesia (BEI) Tahun 2011 - 2015. Jurnal Administrasi Bisnis, Vol. 46 No, 61-68.

Hariza, J. A., Wahyuni, N. I., \& Maria W, S. (2012). Faktor-Faktor Yang Berpengaruh Terhadap Audit Report Lag (Studi Empiris Pada Emiten Industri Keuangan Di Bei). Jurnal Akuntansi Universitas Jember.

Isti, N. (2017). Faktor-Faktor Yang Mempengaruhi Audit Report Lag: Studi Kasus di Indonesia. Jurnal Profita, 4.

Jensen, M., \& Meckling, W. (1976). Theory of the firm: Managerial behavior, agency costs and ownership structure. Journal of Financial Economics. https://doi.org/10.1016/0304405X(76)90026-X

Justira, D. (2017). Pengaruh Profitabilitas, Likuiditas, Solvabilitas, dan Ukuran Perusahaan Terhadap Audit Report Lag Pada Perusahaan Yang Terdaftar di Bursa Efek Indonesia. JIBEKA, 11 No 1, 64-70.

Ketut, D. P., \& Made, Y. L. (2014). Pengaruh Ukuran Perusahaan, Anak Perusahaan, Leverage, dan Ukuran Kantor Akuntan Publik Terhadap Audit Delay. E-Jurnal Akuntansi Universitas Udayana, Vol 8 No 2, 285-299.

Kusumawardani, F. (2013). Faktor-Faktor Yang Mempengaruhi Audit Delay Pada Perusahaan Manufaktur. Accounting Analysis Journal, Vol 2 No 1, 53-58.

Lianto, N., \& Kusuma, H. (2010). Faktor-Faktor Yang Berpengaruh Terhadap Audit Report Lag. Jurnal Bisnis Dan Akuntansi, 12(2), 98-107.

Liwe, A. G., Manossoh, H., \& Mawikere, L. M. (2018). Analisis Faktor-Faktor Yang Mempengaruhi Audit Delay (Studi Empiris Pada Perusahaan Property dan Real Estate Yang Terdaftar di Bursa Efek Indonesia). Jurnal Riset Akuntansi Going Concern, 13(2), 99-108. 
Nisak, K. (2015). Pengaruh Ukuran Perusahaan, Profitabilitas, Solvabilitas, dan Opini Audit Terhadap Audit Delay (Studi Empiris pada Perusahaan Manufaktur yang Terdaftar di BEI Tahun 20082012). Jurnal Akuntansi, Vol 3 No 1, 1-26.

Novice, L., \& Budi, H. K. (2010). Faktor - Faktor Yang Berpengaruh Terhadap Audit Report Lag. Bisnis Dan Akuntansi, 12 No 2, 97-106.

Okalesa. (2018). Analisis Pengaruh Ukuran Perusahaan, ROA dan DAR Terhadap Audit Delay (Studi Empiris Pada Perusahaan Sektor Industri Barang konsumsi Yang Terdaftar Di Bursa Efek Indonesia Tahun 2011-2016). Journal of Economic, Business and Accounting, Volume 1 N, 221232.

Prameswari, A. S., \& Yustrianthe, R. H. (2015). Analisis Faktor-Faktor yang mempengaruhi Audit Delay (Studi Empiris Pada Perusahaan Manufaktur Yang Terdaftar Di Bursa Efek Indonesia). Jurnal Akuntansi, Volume XIX, 50-67.

Putra, P. G. O. S., \& Dwiana, I. M. P. (2016). Ukuran Perusahaan Sebagai Pemoderasi Pengaruh Opini Auditor, Profitabilitas dan Debt To Equity Ratio Terhadap Audit Delay. E-Jurnal Akuntansi Universitas Udayana, 2278-2306.

Rustiarini, N. W., \& Sugiarti, N. W. M. (2013). Pengaruh Karakteristik Auditor, Opini Audit, Audit Tenure, Pergantian Auditor Pada Audit Delay. Jurnal Ilmiah Akuntansi Dan Humanika, Vol 2 No 2, 657-675.

Saemargani, F. I., \& Rr. Indah Mustikawati, M.si., A. (2015). Pengaruh Ukuran Perusahaan, Umur Perusahaan, Profitabilitas, Solvabilitas, Ukuran Kantor Akuntan Publik dan Opini Auditor Terhadap Audit Delay. Jurnal Nominal, Vol IV No.

Sumartini, N. K. A., \& Widhiyani, N. L. S. (2014). Pengaruh Opini Audit, Solvabilitas, Ukuran Kantor Akuntan Publik dan Laba Rugi Pada Audit Report Lag. E-Jurnal Akuntansi Universitas Udayana, Vol 9 NO 1, 392-409.

Togasima, C. N., \& Christiawan, Y. J. (2014). Analisis Faktor-Faktor Yang Mempengaruhi Audit Report Lag Pada Perusahaan Yang Terdaftar Di Bursa Efek Indonesia Pada Tahun 2012. BUSINESS ACCOUNTING REVIEW, Vol 2, No, 151-159.

Widhiasari, N. M. S., \& Budhiarta, I. K. (2016). Pengaruh Umur Perusahaan, Ukuran Perusahaan, Reputasi Auditor dan Pergantian Auditor Terhadap Audit Report Lag. E-Jurnal Akuntansi Universitas Udayana, Vol.15.1., 200-227.

Zakaria, A., Anggraini, R., \& Mutiara, Y. T. (2018). The influence of company size, company profit, solvency and CPA firm size on audit report lag. Pressacademia. https://doi.org/10.17261/Pressacademia.2018.779 